\title{
In vitro evaluation of antileishmanial activity of copper (I) complexes
}

\author{
Ana Flávia da Silva Chagas ${ }^{*} \bullet$, Marina Porchiac®, Francesco Tisatoc $\bullet$, Pauline de Faria \\ Soldera ${ }^{\circledR}$, Claudia Dantas Comandolli Wyrepkowskib®, Maricleide de Farias Naiff ${ }^{\bullet}$, Antonia \\ Maria Ramos Francobø
a Programa de Pós-Graduação em Biotecnologia, Universidade Federal do Amazonas, Manaus, 69067-005, Amazonas, Brasil. *chagas.afs@gmail.com
b Instituto Federal de Pesquisas da Amazônia, Manaus, 69067-375, Amazonas, Brasil.
c Institute of Condensed Matter Chemistry and Technologies for Energy, National Research Council, Pádua, Corso Stati Uniti, 4- \\ 35127, Itália.
}

Received: Outubro 21, 2020 / Accepted: Dezembro 8, 2020 / Published online: January 27, 2021

\begin{abstract}
In the research for the development of new drugs for the therapy of American tegumentary leishmaniasis, copper has been studied for its antileishmania activity. This study aims to report the activity of three copper(I) complexes on parasites of the species Leishmania amazonensis and L. guyanensis. The metal complexes were tested according to in vitro antileishmanial assays, against promastigote and amastigote forms of the most prevalent species in the state of Amazonas, Brazil. Cytotoxicity of the complexes was evaluated in murine macrophage-like cell line (MJ774). The results of the in vitro assays indicated that, among the copper complexes tested, the homoleptic phosphine complex $\left[\mathrm{Cu}(\mathrm{thp})_{4}\right]\left[\mathrm{PF}_{6}\right]$ (thp=tris-hydroxymethylphosphine) presented promising activity against the evolutionary forms of L. amazonensis, and obtained a $\mathrm{IC}_{50}$ of 26.45 and $24.61 \mu \mathrm{M}$ in a period of 48 and $72 \mathrm{~h}$, respectively. The results for copper complex at concentration $160 \mu \mathrm{M}$ in amastigote forms showed a decrease in the infection index (32\% of infected cells) and, in the cytotoxicity assay with MJ774, $52.43 \%$ of cell viability was observed. The results showed that the complex $\left[\mathrm{Cu}(\mathrm{thp})_{4}\right]\left[\mathrm{PF}_{6}\right]$ presented significant biological activity, indicating a need for future in vivo studies.
\end{abstract}

Keywords: Bioassays, Leishmania, leishmaniasis, metal complexes.

\section{Avaliação in vitro da atividade antileishmania de complexos de cobre (I)}

\section{Resumo}

$\mathrm{Na}$ busca do desenvolvimento de novos fármacos para a terapia da leishmaniose tegumentar americana, o cobre tem sido estudado quanto a sua atividade antileishmania. Esse estudo tem como objetivo relatar a atividade de três complexos de cobre (I) sobre parasitas das espécies Leishmania amazonensis e L. guyanensis. Os complexos metálicos foram testados por meio de ensaios antileishmania in vitro contra as formas promastigota e amastigota das espécies mais prevalentes no estado do Amazonas, Brasil. A citotoxicidade dos complexos foi avaliada em linhagem de células semelhantes a macrófagos murinos (MJ774). Os resultados dos ensaios in vitro indicaram que, entre os complexos de cobre testados, o complexo homoléptico de fosfina $[\mathrm{Cu}(\mathrm{thp}) 4][\mathrm{PF} 6]$ (thp=tris-hidroximetilfosfina) apresentou atividade promissora contra as formas evolutivas de $L$. amazonensis, e obtiveram $\mathrm{IC}_{50}$ de 26,45 e $24,61 \mu \mathrm{M}$ em um período de 48 e $72 \mathrm{~h}$, respectivamente. Os resultados para o complexo de cobre na concentração de $160 \mu \mathrm{M}$ nas formas amastigotas reportaram diminuição no índice de infecção (32\% das células infectadas) e, no ensaio de citotoxicidade com MJ774, observou-se 52,43\% de viabilidade celular. Os resultados evidenciaram que o complexo $\left[\mathrm{Cu}(\mathrm{thp})_{4}\right]\left[\mathrm{PF}_{6}\right]$ apresentou atividade biológica significativa, indicando a necessidade de futuros estudos in vivo.

Palavras-chave: Bioensaios, Leishmania, leishmanioses, complexos metálicos.

\section{Introduction}

American cutaneous leishmaniasis (ACL) is a disease caused by different species of the genus Leishmania, and is classified as cutaneous and mucocutaneous (Blanco \& Nascimento-Júnior, 2017). ACL is an endemic disease in 92 countries, and in Brazil it has a high incidence in some of the poorer regions (WHO, 2020).

In 2018, the northern region of Brazil registered 7,519 cases, followed by the northeastern (3,717 cases), midwestern $(2,086)$, southeastern $(1,646)$ and southern $(158)$ 
regions, with the highest numbers of registered cases in the state of Pará (3,081 cases), and Amazonas with 1,684 cases (SINAN, 2019). The northern region of Brazil contributes to the highest incidence of ACL in Brazil due to the diversity of species of Leishmania and sandflies vectors, which is linked to the environmental conditions that favor this transmission.

Currently, meglumine antimoniate, amphotericin B and pentamidine isethionate are the standard drugs adopted for the treatment of leishmaniasis, however the combination of parenteral administration, toxicity and parasitic resistance justifies the search for new active principles (Bastos, Boechat, Hoelz, \& Oliveira, 2016).

The development of metal complexes aimed at treating neglected diseases offers opportunities for pharmaceutical products because of their specific and unique physicochemical properties (Ong, Roy, Andrews, \& Gasser, 2019), variety of coordination numbers, different oxidation states (Selvaganapathy \& Raman, 2016) and the possibility of using a multi-target molecule approach for increasing drug efficiency (Arndt et al., 2017).

Arsenic complexes, mercury, bismuth, platinum, antimony, gold, iron, gadolinium, samarium, technetium, palladium and others are, or have been, used in medicine (Ong et al., 2019). However, copper has been the subject of many studies since it is an essential metal for most aerobic organisms. It is present as a structural and catalytic cofactor of several enzymes (Puig \& Thiele, 2020) and in several studies, such as that by Gandin et al. (2014), it has been shown that copper(I) complexes are capable of inhibiting the growth of tumor cells in vitro and in vivo. Arndt et al. (2017) and Portas, Miguel, YokoyamaYasunaka, Uliana, and Espósito, (2012) demonstrated that different $\mathrm{Cu}(\mathrm{II})$ complexes have antileishmanial activity in vitro against $L$. (L.) amazonensis promastigotes.

According to Tahghighi (2014), the activity of metal complexes depends on the metal oxidation state and on the nature of the ligands. Thus, considering that the mechanism of uptake of copper cells implies a reduction from $\mathrm{Cu}(\mathrm{II})$ to $\mathrm{Cu}(\mathrm{I})$ (Ren et al., 2019), studies such as the one by Saeed et al. (2018) have focused mainly on synthesizing $\mathrm{Cu}(\mathrm{I})$ complexes as potential antileishmanial agents.

A clear example of the importance of the oxidation state of the metal is represented by Navarro et al. (2003a) and Navarro et al. (2003b) studies, in which $\mathrm{Cu}(\mathrm{II})$ and $\mathrm{Cu}(\mathrm{I})$ complexes were synthesized using the ligands ppz (dipyride[3,2-a:2',3'c]phenazine) and dpq (dipyride[3,2-a:2',3'-h]quinoxoline). The compounds showed promising activity, but interestingly the $\mathrm{Cu}(\mathrm{I})\left[\mathrm{Cu}(\mathrm{dppz})_{2}\right] \mathrm{BF}_{4}$ derivative was shown to be more active in $L$. (L.) mexicana promastigotes than the corresponding $\mathrm{Cu}(\mathrm{II})$ derivative $\left[\mathrm{Cu}(\mathrm{dppz})_{2}\left(\mathrm{NO}_{3}\right)\right]\left(\mathrm{NO}_{3}\right)$ that was tested on $L$. (V.) braziliensis promastigotes.

This study aims to report the activity of three copper(I) complexes on parasites of the species $L$. amazonensis and $L$. guyanensis.

\section{Materials and Methods}

\section{Copper complexes}

The synthesis of the copper(I) complexes $\left[\mathrm{Cu}(\text { thp })_{4}\right]\left[\mathrm{PF}_{6}\right]$ (thp = tris-hydroxymethylphosphine) $(1),\left[\mathrm{Cu}(\mathrm{PTA})_{4}\right]\left[\mathrm{BF}_{4}\right]$ $(\mathrm{PTA}=1,3,5$-triaza-7-phosphadamantane) (2) and $\left[\mathrm{HB}(\mathrm{pz})_{3} \mathrm{Cu}(\mathrm{PTA})\right]\left(\mathrm{HB}(\mathrm{pz})_{3}=\right.$ tris(pyrazolyl)borate) (3) (Figure 1) was carried out according to the procedures of Marzano et al. (2008), Porchia et al.(2009) and Gandin et al. (2014).

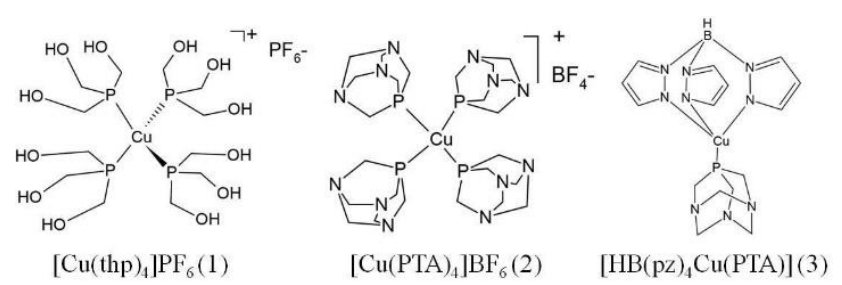

Figure 1. Chemical structures of $\mathrm{Cu}(\mathrm{I})$ complexes used in this study.

To perform the biological assays, the copper complexes were dissolved in dimethyl sulfoxide (DMSO - Vetec ${ }^{\circledR}, 4 \%$ $\mathrm{v} / \mathrm{v}$ ) and Schneider medium, filtered through a membrane with $0.22 \mu \mathrm{m}$ pores, under sterile conditions. In the promastigote assay, concentrations ranging from 160 to 10 $\mu \mathrm{M}$ of the copper complexes were tested using serial dilution, and for the cytotoxicity and amastigote assays, a $160 \mu \mathrm{M}$ concentration of the copper complex was evaluated. For control tests, the standard drug used was pentamidine isethionate (Pentacarinat ${ }^{\circledR}$ ) (Sanofi Aventis Farmacêutica Ltda, Brazil), diluted in Schneider's insect medium (SigmaAldrich $^{\circledR}$ ), and filtered through a syringe filter (Kasvi, 0.22 $\mu \mathrm{m})$, under sterile conditions. In the promastigote and cytotoxicity assays, ranging concentrations from 9.1 to 147 $\mu \mathrm{M}$ of the Pentacarinat ${ }^{\circledR}$ were tested by serial dilution means and in amastigotes (intracellular form) assays, $147 \mu \mathrm{M}$ concentration of the Pentacarinat ${ }^{\circledR}$ was evaluated.

\section{Origin and maintenance of parasites}

Leishmania (Leishmania) amazonensis (MHO/BR/2006/IM5584) and Leishmania (Viannia) guyanensis (MHO/BR/95/M4147) were characterized, cryopreserved and maintained in the Laboratory of Leishmaniasis and Chagas' Disease, National Institute of Amazonian Research - INPA (Manaus, Amazon, Brazil). The parasites were cultured in a Novy-MacNeal-Nicolle medium (NNN). This culture was expanded in complete Schneider's insect medium (Sigma-Aldrich ${ }^{\circledR}$ ), which was supplemented with $10 \%$ of inactivated fetal calf serum (iFCS) and gentamicin $40 \mu \mathrm{g} \mathrm{mL}^{-1}$ (Novafarma, Brazil). The J774 macrophages were kept in culture bottles with complete RPMI 1640 medium (Himedia ${ }^{\circledR}$ ), supplemented with $20 \%$ of iFCS, and incubated in an oven at $37^{\circ} \mathrm{C}$.

\section{In vitro promastigote assay}

In 96-well plates promastigote forms $\left(2 \times 10^{6}\right.$ cells $\left./ \mathrm{mL}\right)$ were exposed to different concentrations of copper complexes (10 to $160 \mu \mathrm{M})$. The control groups consisted of promastigotes treated with Pentacarinat ${ }^{\circledR}$ (9.1 to $147 \mu \mathrm{M}$ ) and promastigotes without treatment, the DMSO concentration ranged from $0.06 \%$ to $1 \%$ in the plate. The biological activity was determined by inhibiting the growth 
of promastigote forms of Leishmania spp. and quantifying viable promastigotes in a hemocytometer using an optical microscope (Nikon Eclipse E200, Nikon, Japan) at 400x magnification, at 24, 48 and 72 hour intervals. Data are expressed as a half-maximum inhibitory concentration $\left(\mathrm{IC}_{50}\right)$ and parasitic viability is compared with the controls (Comandolli-Wyrepkowski et al., 2017).

\section{In vitro cytotoxicity assay}

The murine macrophage-like cell line $\mathrm{J} 774\left(10^{5}\right.$ cells $\left.\mathrm{mL}^{-1}\right)$ were incubated in 96-well plate in a complete Schneider medium at $37{ }^{\circ} \mathrm{C}$. After 24 hours of cell adhesion. The cells were only exposed to the copper complex (1) that showed the best performance in the assay against promastigote forms, and the control groups consisted of cells treated with Pentacarinat ${ }^{\circledR}$ and cells without treatment, for a period of 24, 48 and 72 hours.

To determine cell viability, the MTT colorimetric test $\left(\right.$ Roche $^{\circledR}$ ) was used, after the incubation periods of 24, 48 and 72 hours. Subsequently, the optical density (OD) of each well plate was evaluated on the spectrophotometer $\left(\right.$ Bio-TEK $\left.^{\circledR}\right)$ at $590 \mathrm{~nm}$. For morphological evaluation, a 24-well plate was used, with the same conditions for cultivation and treatment of the cells, with subsequent fixation and staining of the biological material by the Rapid Panoptic method (Laborclin ${ }^{\circledR}$, Paraná, Brazil). The results were expressed as the percentage of viable cells (Comandolli-Wyrepkowski et al., 2017).

\section{In vitro amastigote-macrophage assay}

Macrophages were incubated on a 24 -well plate with $10^{5}$ cells $\mathrm{mL}^{-1}$ in complete Schneider medium, incubated in an oven at $37{ }^{\circ} \mathrm{C}$ for 48 hours. Macrophages were then infected with $10^{6}$ cells $\mathrm{mL}^{-1}$ for 2 hours with the L. (L.) amazonensis or L. (V.) guyanensis promastigotes. After the infection period, the wells were washed with sterile saline solution $(\mathrm{NaCl} 0.9 \%)$ for removal of the non-internalized promastigotes. The infected macrophages were incubated for 48 hours at $37^{\circ} \mathrm{C}$ in the presence of copper complex (1) $(160 \mu \mathrm{M})$ and Pentacarinat $^{\circledR}(147 \mu \mathrm{M})$. After the incubation period, the wells were washed with sterile saline solution and the macrophages were then fixed and stained using the Quick Panoptic $\left(\right.$ Laborclin $^{\circledR}$ ). For the analysis, 100 macrophages were quantified (in triplicate) to determine infection rate considering infected and uninfected macrophages. Quantification was performed using an optical microscope at 1000x magnification (Comandolli-Wyrepkowski et al., 2017).

\section{Statistical analysis}

All biological assays were performed in triplicate and the results were expressed as average \pm standard deviation (SD). The data were submitted to one-away analysis of variance and $p$ values below 0.05 were considered significant. Tukey's multiple comparison test was used to identify significant differences in the means among the different treatments (GraphPad Prism software, version 6.0).

\section{Results and Discusion}

In the promastigote cells sensitivity test to the three copper complexes, both species of Leishmania showed different behavior after cultivation in the presence of complexes. There was a significant difference between all treatments ( $p$ $<0.001)$ in the two species tested. The most promising complex against promastigote forms of $L$. (L.) amazonensis was complex (1), which presented an $\mathrm{IC}_{50}$ of 26.45 and 24.61 $\mu \mathrm{M}$ at 48 and 72 hours, respectively. This $\mathrm{IC}_{50}$ was lower than that for Pentacarinat ${ }^{\circledR}$, however this complex did not present a similar activity against L. (V.) guyanensis (Table 1).

Table 1 . Inibitory Concentrations $\left(\mathrm{IC}_{50}\right)$ of copper complexes $(1,2,3)$ and Pentacarinat ${ }^{\circledR}$ calculated by linear regression, in 48 and 72 hour incubation periods with promastigotes of Leishmania (Leishmania) amazonensis and Leishmania (Viannia) guyanensis.

\begin{tabular}{|c|c|c|}
\hline \multirow{2}{*}{ Copper complexes } & \multicolumn{2}{|c|}{ L. amazonensis } \\
\hline & $48 \mathrm{~h}$ & $72 \mathrm{~h}$ \\
\hline$\left[\mathrm{Cu}(\mathrm{thp})_{4}\right]\left[\mathrm{PF}_{6}\right](1)$ & $26.45 \pm 0.24$ & $24.61 \pm 0.28$ \\
\hline$\left[\mathrm{Cu}(\mathrm{PTA})_{4}\right]\left[\mathrm{BF}_{4}\right](2)$ & $89.26 \pm 0.79$ & $75.03 \pm 0.65$ \\
\hline$\left[\mathrm{HB}(\mathrm{pz})_{3} \mathrm{Cu}(\mathrm{PTA})\right](3)$ & $87.17 \pm 0.76$ & $62.11 \pm 0.42$ \\
\hline Pentacarinat ${ }^{\circledR}$ & $66.28 \pm 0.18$ & $27.45 \pm 0.61$ \\
\hline \multirow{2}{*}{ Copper complexes } & \multicolumn{2}{|c|}{ L. guyanensis } \\
\hline & $48 \mathrm{~h}$ & $72 \mathrm{~h}$ \\
\hline$\left[\mathrm{Cu}(\text { thp })_{4}\right]\left[\mathrm{PF}_{6}\right](1)$ & $105.94 \pm 0.01$ & $177.10 \pm 0.03$ \\
\hline$\left[\mathrm{Cu}(\mathrm{PTA})_{4}\right]\left[\mathrm{BF}_{4}\right](2)$ & $330.23 \pm 0.05$ & $155.49 \pm 0.03$ \\
\hline$\left[\mathrm{HB}(\mathrm{pz})_{3} \mathrm{Cu}(\mathrm{PTA})\right](3)$ & $207.43 \pm 0.01$ & $120.36 \pm 0.00$ \\
\hline Pentacarinat ${ }^{\circledR}$ & $61.55 \pm 0.02$ & $58.10 \pm 0.00$ \\
\hline
\end{tabular}

Considering complex (1) as the most promising, we analyzed the statistical difference between the treatments and the different concentrations of the complex (1). In L. (L.) amazonensis promastigotes, complex (1) showed a significant difference to the negative control in 48 hours ( $p$ $=0.0029)$ and 72 hours $(p=0.0133)$, with less parasitic viability. There was also a significant difference between the complex (1) and Pentacarinat ${ }^{\circledR}$ in the period of 48 hours $(p=$ $0.0049)$ and 72 hours $(p=0.0007)$, with greater parasitic viability being observed in the lower concentrations of the complex (1) [Figure 2].

In promastigote forms of $L$. (V.) guyanensis, complex (1) showed a significant difference, with less minor parasitic viability when compared to the negative control in the 48 hour period ( $p=0.0429$ ); complex (1) also showed greater parasitic viability compared to Pentacarinat $^{\circledR}$, with significant difference in the period of 48 hours $(p=0.0027)$ and 72 hours $(p=0.0055)$ [Figure 2].

In the cytotoxicity test, the results showed that $52.45 \%$ (SD 1.29\%) of the MJ774 cells were viable after 48 hours of incubation with complex (1) at concentration $160 \mu \mathrm{M}$. Moreover, morphological analysis of the cells exposed to complex (1) revealed that in the positive control (untreated macrophages) and Pentacarinat ${ }^{\circledR}$ assays (Figure 3A and B, respectively), the MJ774 cells did not present any morphological alterations, whereas when using treatment with complex (1) the presence of vacuoles in the cytoplasm was notable (Figure 3C).

Thus, the effectiveness of complex (1) was tested against the amastigote forms of $L$. (L.) amazonensis and $L$. (V.) guyanensis internalized in MJ774 cells. The results showed that the rate of infection of L. (L.) amazonensis was 32\% (SD 
$1.4 \%$ ) when macrophages were treated with a $160 \mu \mathrm{M}$ concentration of complex (1), and 19\% (SD 0.90\%) when treated with Pentacarinat ${ }^{\circledR}$.

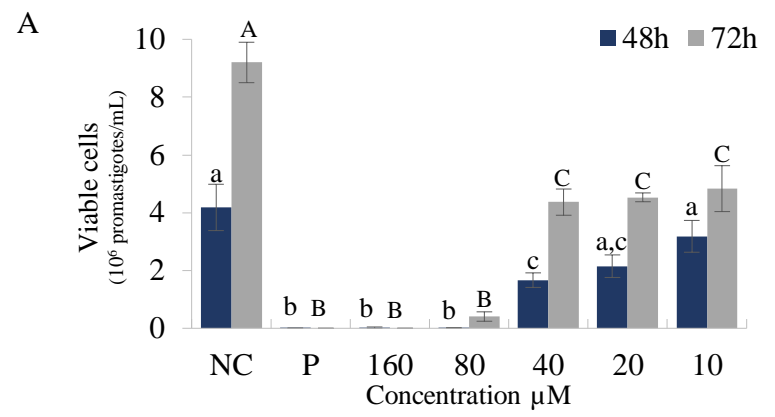

B

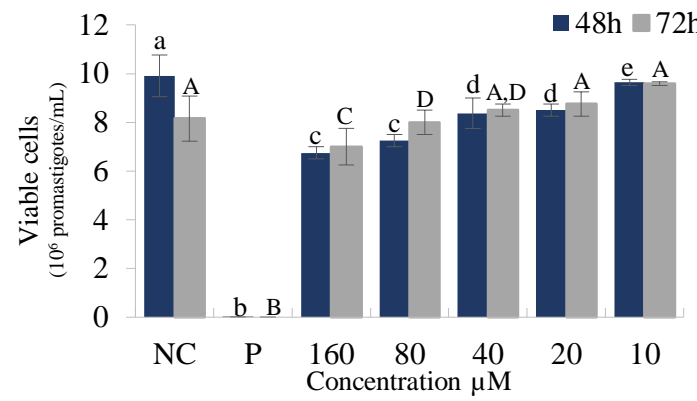

Figure 2. Antileishmanial activity of the copper complex (1) in promastigote forms of Leishmania (Leishmania) amazonensis (A) and L. (Viannia) guyanensis (B). Legend: NC: Negative control; P: Pentacarinat ${ }^{\circledR}(147 \mu \mathrm{M})$. Means followed by the same lowercase (for $48 \mathrm{~h}$ interval) and uppercase (for $72 \mathrm{~h}$ ) letters, in each graphic, do not differ from each other by the Tukey test at $5 \%$ probability.
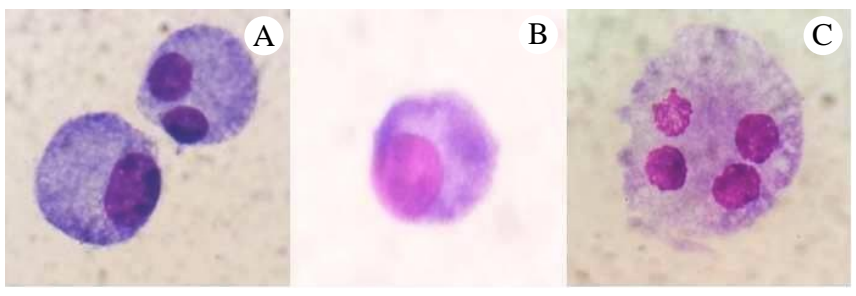

Figure 3. In vitro cytotoxicity morphological assay with MJ774 cells after 48 hours of incubation. A: Positive control (untreated macrophages), B: macrophages treated with Pentacarinat $^{\circledR}$ C) macrophages treated with $160 \mu \mathrm{M}$ of copper complex (1). $1000 \mathrm{x}$ magnification. This figure is in color in the electronic version.

The morphological analysis of the cells exposed to the in vitro amastigote-macrophage assay revealed that the infected and untreated macrophages showed internalized amastigotes with the presence of small vacuoles, and the same was observed in infected macrophages and those treated with Pentacarinat $^{\circledR}$. When the infected macrophages were treated with complex (1), the presence of amastigotes interiorized in vacuoles was observed, in addition to the intense vacuolization of the macrophages (Figure 4).

When the macrophages were infected with L. (V.) guyanensis and treated with a $160 \mu \mathrm{M}$ concentration of complex (1), there was a total lysis of the macrophages, and was considered a $100 \%$ infection, therefore it was not possible 4 to perform morphological records due to cellular degradation.

In a research conducted by Portas et al. (2012), using copper(II) complexes, also observed antileishmanial activity against promastigote forms of $L$. (L.) amazonensis. The results showed that the acetylacetonate (acac) derivative, namely $\mathrm{Cu}(\mathrm{acac})_{2}$, showed the best activity at 24 hours with an $\mathrm{IC}_{50}$ of $31 \mu \mathrm{M}$, but demonstrated an increase during the incubation period ( $\mathrm{IC}_{50}$ of $94 \mu \mathrm{M}$ at 72 hours), whereas the more lipophilic fluoroderivative $\mathrm{Cu}(\mathrm{tfacac})_{2}$ increased its activity during the incubation period ( $\mathrm{IC}_{50}$ of 68 and $43.0 \mu \mathrm{M}$ at 24 and 72 hours respectively).

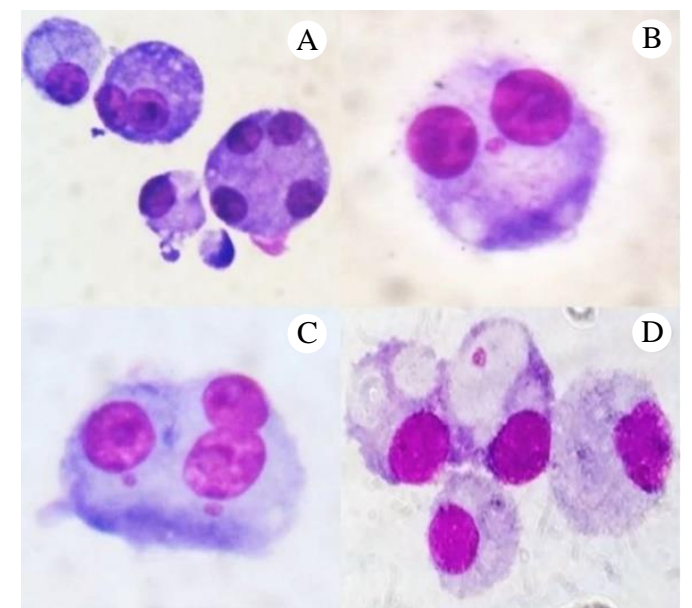

Figure 4. In vitro amastigote - macrophage assay with Leishmania (Leishmania) amazonensis. A) Positive control (non-infected and untreated macrophages, B) infected and untreated macrophages, C) infected macrophages and treated with Pentacarinat ${ }^{\circledR}$ and D) infected macrophages and treated with $160 \mu \mathrm{M}$ of copper complex (1). 1000x magnification. This figure is in color in the electronic version.

The key factors for the efficacy of the $\mathrm{Cu}(\mathrm{II})$ complexes tested by Portas et al. (2012) are the high lipophilicity and the pro-oxidant activity, as lipophilic complexes are better inhibitors of trypanothione reductase (TR). In our case, we used water-soluble, or highly hydrophilic, $\mathrm{Cu}(\mathrm{I})$ compounds that presented a lower or a similar $\mathrm{IC}_{50}$ compared to those reported in the literature, suggesting a different mechanism of action.

In particular, complex (1) demonstrated itself to be the most promising against the promastigote forms of $L$. (L.) amazonensis when compared to the other two complexes tested, presenting an $\mathrm{IC}_{50}$ value lower than the values reported in previous studies ( $\mathrm{IC}_{50}$ of 26.45 and $24.61 \mu \mathrm{M}$ at 48 and 72 hours). Regarding the activity of the copper(I) complex against L. (V.) guyanensis, there was a decline in the $\mathrm{IC}_{50}$, suggesting a long-term activity. However, no other study was found that used copper complexes against $L$. (V.) guyanensis.

Complex (2) is a homoleptic compound comprising the metal tetrahedrally arranged in a cationic moiety, which differs from complex (1) due to the nature of the phosphine (PTA instead of thp). This difference demonstrated a noticeable decrease in the activity against $L$. (L.) amazonensis, leading to $\mathrm{IC}_{50}$ values of 89.26 and $75.03 \mu \mathrm{M}$ 
at 48 and 72 hours respectively, which is about three times higher than those obtained with complex (1). As observed for complex (1), complex (2) was also even less active against $L$. $\left(V\right.$.) guyanensis, showing significant increase in $\mathrm{IC}_{50}$ during the incubation period ( $\mathrm{IC}_{50}$ of 330.23 and $155.49 \mu \mathrm{M}$ at 48 and 72 hours, respectively).

Compound (3) is a lipophilic neutral mixed-ligand (scorpionate/phosphane) species, and its mechanism of internalization and of action might be different from those of complexes (1) and (2). In fact, complexes (1) and (2) in diluted solutions, such as those utilized for biological tests, are partially dissociated and the predominant species in the solution are the coordinatively unsaturated $\mathrm{CuP}_{2}^{+} / \mathrm{CuP}_{3}{ }^{+}$ species. These can be internalized in the cell by an active transport mechanism using Ctr1 transporters, whereas compound (3), even at low concentrations, does not lose ligands and remains as a neutral lipophilic entity that can be internalized by a passive diffusion transport mechanism (Gandin et al., 2014; Tisato et al., 2016; Quaretti et al., 2018).

In fact, as it appears from the $\mathrm{IC}_{50}$ values, the activity of (3) is similar, or slightly better, than the activity of (2), suggesting that lipophilicity is not the key factor. However, as in the study by Portas et al. (2012), compound (3) showed lipophilicity and obtained a decrease in $\mathrm{IC}_{50}$ during the incubation period, suggesting long-term activity.

In the literature, the activity of a cationic drug, such as paromomicyn, can be related to its ability to bind to the negatively-charged leishmanial glycoprotein-polysaccharide layer covering the cell membrane (Jhingran, Chawla, Saxena, Barrett, \& Madhubala, 2009). In our case, both complexes (1) and (2) are positively charged, so the charge is not a key factor for explaining the remarkable activity of (1). Among the three complexes tested, (1) is the most active compound against both evolutionary forms of the life cycle of $L$. (L.) amazonensis.

Further studies are needed to elucidate the mechanism(s) of action of the compounds tested in this study, in particular their ability to inhibit TR, since this is an enzyme which is exclusive to organisms that belong to the Trypanosomatidae family, this made it a potential chemotherapeutic target. In addition, it was found that antimony compounds have the ability to inhibit TR, which may be one of the mechanisms of action for the current treatment of leishmaniasis (Tunes et al., 2020). Studies, such as the one by Tunes et al. (2020), have sought to investigate the ability of gold complexes to inhibit TR and it was found that gold complexes were active against Leishmania spp. $\left(\mathrm{IC}_{50}\right.$ of 0.5 to $5.5 \mu \mathrm{M}$ ) and all gold(I) complexes were potent inhibitors of TR, which demonstrates that although antileishmanial activity may involve several mechanisms, one strategy is to ascertain the potential for inhibiting TR.

In relation to cytotoxicity, Singh et al. (2017) performed biological cytotoxicity assays on macrophages of mammalian hosts and the results revealed that copper salisylaldoxime (30 $\mu \mathrm{M}$ and $45 \mu \mathrm{M})$ is almost non-toxic to host cells. In our study, we observed intense vacuolization in macrophages treated with complex (1). This fact may be associated with the mechanisms described by Tisato et al. (2016), who suggested that complex (1) does not induce cell apoptosis or DNA fragmentation, but it does induce cell paraptosis through the stress of the endoplasmic reticulum in cancer cells, causing their death.
In experimental studies with intracellular forms, Britta et al. (2012) evaluated the activity of a copper complex against L. (L.) amazonensis and the infectivity rate was $62.3 \%$ to $14.4 \%$. The results presented for Britta et al. (2012) are similar to those of this study since the infectivity rate was $32 \%$.

A relevant factor in assays with amastigote forms was the intense vacuolization of macrophages exposed to complex (1), which maybe associated with an increase in infection. Young and Kima (2019) recently showed that $L$. (L.) amazonensis infections are more successful when autophagy increases in host cells, in addition to an increase in parasitic load in BALB/c macrophages.

\section{Conclusion}

The phosphine copper(I) complex $\left[\mathrm{Cu}(\text { thp })_{4}\right]\left[\mathrm{PF}_{6}\right]($ thp $=$ tris-hydroxymethylphosphine) (1) presented promising activity against both evolutionary forms in the life cycle of $L$. (L.) amazonensis and showed moderate toxicity in murine macrophage line J774 in the concentration tested in this study.

\section{Acknowledgments}

The authors would like to thank the Conselho Nacional de Desenvolvimento Científico e Tecnológico - CNPq, Fundação de Amparo à Pesquisa do Estado do Amazonas FAPEAM, and FP7-PEOPLE-2011-IRSES- 295262: VAIKUTUS for their financial support.

\section{References}

Arndt, A., Liria, C. W., Yokoyama-Yasunaka, J. K. U., Manchini, M. T., Uliana, S. R. B. and Espósito, B. P. (2017). New iminodibenzyl derivatives with anti-leishmanial activity. Journal of Inorganic Biochemistry, 172, 9-15. doi: 10.1016/j.jinorgbio.2017.04.004.

Bastos, M. M., Boechat, N., Hoelz, L. V. B. \& de Oliveira, A. P. (2016). Quimioterapia antileishmania: Uma revisão bibliográfica. Revista Virtual de Química, 8(6), 2072-2104. doi: 10.21577/19846835.20160139.

Blanco, V.R. and Nascimento-Júnior N.M. (2017). Leishmaniose: Aspectos gerais relacionados com a doença, o ciclo do parasita, fármacos disponíveis, novos protótipos e vacinas. Revista Virtual de Química, 9(3), 861-876. doi: 10.21577/1984-6835.20170055.

Britta, E. A., Silva, A. P. B., Ueda-Nakamura, T., Dias-Filho, B. P., Silva, C. C., Sernaglia, R. L and Nakamura, C. V. (2012). Benzaldehyde thiosemicarbazone derived from limonene complexed with copper induced mitochondrial dysfunction in Leishmania amazonensis. PLoS ONE, 7(8), e41440. doi: 10.1371/journal.pone.0041440.

Comandolli-Wyrepkowski, C. D., Jensen, B. B., Grafova, I., Santos, P. A., Barros, A. M. C., Soares, F. V., Barcellos, J. F. M., Silva, A. F., Grafov, A. and Franco, A. M. R. (2017). Antileishmanial activity of extracts from Libidibia ferrea: development of in vitro and in vivo tests. Acta Amazonica, 47(4), 331-340. doi: 10.1590/1809-4392201700871.

Gandin, V., Tisato, F., Dolmella, A., Pellei, M., Santini, C., Giorgetti, M., Marzano, C. and Porchia, M. (2014). In vitro and in vivo anticancer activity of copper(I) complexes with homoscorpionate tridentate tris(pyrazolyl)borate and auxiliary monodentate phosphine ligands. Journal of Medicinal Chemistry, 57(11). doi:10.1021/jm500279x.

Jhingran, A., Chawla, B., Saxena, S., Barrett, M. P. and Madhubala, R. (2009). Paromomycin: uptake and resistance in Leishmania Donovani. Molecular and Biochemical Parasitology, 164(2), 111-117. doi: 10.1016/j.molbiopara.2008.12.007.

Marzano, C., Gandin, V. Pellei, M., Colavito, D., Papini, G., Lobbia, G.G., Giudice, E.D., Porchia, M. Tisato, F. and Santini, C. (2008). In vitro 
antitumor activity of the water soluble copper(I) complexes bearing the tris(hydroxymethyl)phosphine ligand. Journal of Medicinal Chemistry, 51(4), 798-808. doi: 10.1021/jm701146c.

Navarro, M., Cisneros-Fajardo, E. J., Fernandez-Mestre, M., Arrieche, D. and Marchan, E. (2003a). Synthesis, characterization, DNA binding study and biological activity against Leishmania mexicana of $\left[\mathrm{Cu}(\mathrm{dppz})_{2}\right] \mathrm{BF}_{4}$. Journal of Inorganic Biochemistry, 97(4), 364-369. doi: 10.1016/s01620134(03)00290-3.

Navarro, M., Cisneros-Fajardo, E. J., Sierralta, A., Fernández-Mestre, M., Silva, P., Arrieche, D. and Marchán, E. (2003b). Design of copper DNA intercalators with leishmanicidal activity. Journal of Biological Inorganic Chemistry, 8, 401-408. doi: 10.1007/s00775-002-0427-2.

Ong, Y. C., Roy, S., Andrews, P. C. and Gasser, G. (2019). Metal compounds against neglected tropical diseases. Chemical Reviews, 119(2), 730-796. doi: 10.1021/acs.chemrev.8b00338.

Porchia, M., Benetollo, F., Refosco, F., Tisato, F., Marzano, C. and Gandin, V. (2009). Synthesis and structural characterization of copper(I) complexes bearing N-methyl-1,3,5-triaza-7-phosphaadamantane (mPTA): Cytotoxic activity evaluation of a series of water soluble $\mathrm{Cu}(\mathrm{I})$ derivatives containing PTA, PTAH and mPTA ligands. Journal of Inorganic Biochemistry, 103(12), 1644-1651. doi: 10.1016/j.jinorgbio.2009.09.005.

Portas, A. S., Miguel, D. C., Yokoyama-Yasunaka, J. K. U., Uliana, S. R B. and Espósito, B. P. (2012). Increasing the activity of copper(II) complexes against Leishmania through lipophilicity and pro-oxidant ability. Journal of Biological Inorganic Chemistry, 17, 107-112. doi: 10.1007/s00775-011-0834-3.

Puig, S. and Thiele, D. J. (2020). Molecular mechanisms of copper uptake and distribution. Current Opinion in Chemical Biology, 6(2), 171-180. doi: 10.1016/s1367-5931(02)00298-3.

Quaretti, M., Porchia, M., Tisato, F., Trapananti, A., Aquilanti, G., Damjanović, M., Marchiò, L., Giogertti, M. and Tegoni, M. (2018). Thermodynamic stability and structure in aqueous solution of the $\left[\mathrm{Cu}(\mathrm{PTA})_{4}\right]^{+}$complex $(\mathrm{PTA}=$ aminophosphine 1,3,5-triaza-7phosphaadamantane). Journal of Inorganic Biochemistry, 188, 50-61. doi: 10.1016/j.jinorgbio.2018.08.008.

Ren, F., Logeman, B.L., Zhang, X., Liu, Y., Thiele, D.J. and Yuan, P. (2019). $\mathrm{X}$-ray structures of the high-affinity copper transporter Ctr1. Nature Communication, 10(1386). doi: 10.1038/s41467-019-09376-7.

Saeed, A., Larik, F. A., Jabeen, F., Mehfooz, H., Ghumro, S. A., El-Seedi, H.R., Ali., M., Channar, P. A. and Ashraf. H. (2018). Synthesis, antibacterial and antileishmanial activity, cytotoxicity, and molecular docking of new heteroleptic copper(I) complexes with thiourea ligands and triphenylphosphine. Russian Journal of General Chemistry, 88(3), 541-550. doi: 10.1134/S1070363218030246.

Selvaganapathy, M. and Raman, N., (2016). Pharmacological activity of a few transition metal complexes: a short review. Journal of Chemical Biology \& Therapeutics, 1(2), 108. doi: 10.4172/2572-0406.1000108.

Sinan/SVS/MS [database on the Internet] Casos de Leishmaniose Tegumentar. Brasil, Grandes Regiões e Unidades Federadas. 1990 a 2018. Available in: https://portalarquivos2.saude.gov.br/images/pdf/2019/outubro/14/LTCasos.pdf.

Singh, M. K, Bhaumik, S. K., Karmakar, S., Paul, J., Sawoo, S., Majumder, H.K. and Roy, A. (2017). Copper salisylaldoxime (CuSAL) imparts protective efficacy against visceral leishmaniasis by targeting Leishmania donovani topoisomerase IB. Experimental Parasitology, 175, 8-20. doi: 10.1016/j.exppara.2017.02.010.

Tahghighi, A. (2014). Importance of metal complexes for development of potential leishmanicidal agents. Journal of Organometallic Chemistry, 770, 51-60. doi: 10.1016/j.jorganchem.2014.08.007.

Tisato, F., Marzano, C., Peruzzo, V., Tegoni, M., Giorgetti, M., Damjanovic, M., Trapananti, A., Bagno, A., Santini, C., Pellei, M., Porchia, M. and Gandin, V. (2016). Insights into the cytotoxic activity of the phosphane copper(I) complex $\left[\mathrm{Cu}(\mathrm{thp})_{4}\right]\left[\mathrm{PF}_{6}\right]$. Journal of Inorganic Biochemistry, 165, 80-91. doi: 10.1016/j.jinorgbio.2016.07.007.

Tunes, L. G., Morato, R. E., Garcia, A., Schmitz, V., Steindel, M., CôrreaJunior, J. D., Santos, H. F. D., Frézard, F., Almeida, M. V., Silva, H., Moretti, N. S., Barros, A. L. B. and Monte-Neto, R. L. (2020). Preclinical gold complexes as oral drug candidates to treat leishmaniasis are potent trypanothione reductase inhibitors. ACS Infectious Disease, 6(5), 11211139. doi: 10.1021/acsinfecdis.9b00505.
WHO. World Health Organization [homepage on the Internet]. Leishmaniasis. Available in: https://www.who.int/healthtopics/leishmaniasis\#tab=tab_1.

Young, J. and Kima, P.E. (2019). The Leishmania parasitophorous vacuole membrane at the parasite-host interface. Yale Journal of Biology and Medicine, 92(3): 511-521. Recovered from: https://www.ncbi.nlm.nih.gov/pmc/articles/PMC6747952/.

\section{License: Creative Commons CC BY 4.0}

This article was published with open access for distribution under the terms of the Creative Commons Attribution License, which allows unrestricted use, distribution, and reproduction in any medium, provided the original work is properly cited. 